\title{
Highly skilled returnees and the internationalization of EMNEs: Firm level evidence from China
}

\author{
Xialoan Fu \\ TMCD, Department of International Development, University of Oxford, Email: xiaolan.fu@qeh.ox.ac.uk \\ Jun Hou \\ TMCD, Department of International Development, University of Oxford, Email: jun.hou@qeh.ox.ac.uk \\ Marco Sanfilippo* \\ Institute of Development Policy and Management, University of Antwerp, Email: \\ marco.sanfilippo@uantwerp.be
}

Jan 2016

\begin{abstract}
This paper examines how Chinese firms acquire knowledge and experience in international markets by attracting returnees using an original firm level survey from Guangdong province. It finds that there is a strong and positive relation between a firm's choice of hiring returnees and its propensity to embark in FDI. Moreover, it shows that not all returnees contribute equally to firms' internationalization. It is mainly those individuals in the most strategic functions, such as management and sales to determine both the propensity and the level of overseas direct investment. Finally, it finds that the presence of returnees is particularly effective for less experienced firms since it can help reduce the time taken to build capabilities and provide direct access to the knowledge necessary to invest abroad.
\end{abstract}

Keywords: China; Returnees; Foreign Direct Investment; Internationalization JEL Codes: F22; F23 


\section{Introduction}

Outward Foreign Direct Investments (OFDI) from China and the globalization of Chinese firms have become increasingly debated topics in the wake of the "Going Global" policies, officially implemented with the tenth Five Year Plan in 2001. Since then, OFDI from China have risen rapidly, even during the financial crisis. A large strand of research has emerged to investigate this phenomenon (Buckley et al., 2007). Most studies find that Chinese Multinational Enterprises (MNEs) show a different pattern from traditional investors (Child and Rodrigues, 2005), characterized by an active role by the Government (Buckley et al., 2008) and unconventional motivations to invest, e.g. the prevalence of asset exploring over asset exploitation motivations especially when OFDI is directed to more developed countries (Deng, 2012; Fu, et al., 2013). Within this literature, some emphasis has been given to the fact that Chinese MNEs, as latecomers in international markets, often invest abroad with little or no prior experience of cross border operations. Research shows they lack internal management capacities and a complete understanding of managerial practices and the social and economic aspects of the host country markets (Rugman and Li, 2007; Nolan, 2012; EIU, 2010). Since some of these constraints to the country's globalization can be attributed to a shortage of talents to serve the needs of MNEs, increasing attention is now being given to highly skilled returnees and their role in fostering the country's Going Global strategy (Wang et al., 2011).

Evidence is now rich on the so-called Chinese Knowledge Diaspora ${ }^{1}$. Since 1978, about half of the 2 million students who went abroad came back to China, a trend that has increased rapidly in the last few years. Highly skilled returnees played an important role in China's development and many of them have contributed to the growth of some of the most dynamic private firms in high technology sectors and emerging industries, such as the photovoltaic. Highly skilled returnees are strongly represented in the top management of some of the most internationalized investors, including Lenovo and the China Investment Corporation (Liu et al., 2010; Luo et al., 2013; Wang, 2012).

Yet the extent and nature of the contribution made to the OFDI of Chinese MNEs by highly skilled returnees is under-investigated. Due to the lack of detailed firm level information on the presence of returnees in Chinese companies, very little research has so far investigated this nexus empirically. Furthermore, the existing evidence on this topic suffers from at least two relevant shortcomings. First, returnees are normally regarded as a homogeneous group of high-skilled individuals that can directly contribute to the overall upgrading of Chinese firms. However, the extent to which returnees can affect internationalization is moderated by the effective role they play (Cui et al., 2014), and their capacity to affect a company's corporate governance (Lee and Roberts, 2015; Giannetti et al., 2015). Therefore, it is important to examine to what extent do the different skills sets and hence different roles of the returnees may affect a firm's internationalization process differently, and identify the most influential types of

\footnotetext{
${ }^{1}$ Global knowledge diaspora are a recent phenomenon sustained by both increases in global migration flows and ICT development (Welch and Zhang, 2007).
} 
returnees by their functional roles in a firm. Second, little is still known about the ways through which returnees can affect firms' internationalization and whether this relation changes according to firms' characteristics. In particular, while some firms are rich in international operations and enjoy a competitive advantage, some need to balance the pressure to expand internationally with the lack of a complete set of competitive advantages to exploit (Cui et al., 2013). This is an argument that precisely fits the case of EMNEs. Their status of latecomers in international markets has often forced them to invest at earlier stages in their organizational development (Luo and Tung, 2007). How do such characteristics affect the impact of returnees in a firm's internationalization? In other words, in which type of firms does attracting returnees have a bigger impact? These are two important gaps in the literature that have important managerial implications.

With this paper we aim to contribute to fill these gaps, shading light on a specific channel (the attraction of high-skilled returnees) through which Chinese firms acquire knowledge and experience to explore foreign markets through FDI. We base our analysis on an original firm level survey from Guangdong province. The focus on firms from Guangdong is particularly relevant for the aim of this research, since this is the largest source of outward FDI among all Chinese provinces and among the most attractive locations for highly skilled migrants.

Our empirical analysis is grounded in the knowledge-based view (KBV) and the organizational learning perspective as well as more recent developments to account for the rise of latecomer MNEs from emerging economies. While knowledge is the most valuable resource to the firm, the way it is acquired crucially affects the choice of internationalization. Among the different channels of learning discussed in the literature, that related to the role of returnees is especially relevant to understand the process through which firms acquire experiential knowledge necessary to explore foreign markets via FDI or to internationalize to access foreign resources, knowledge or enhance production efficiency.

Our empirical results based on Probit and Tobit models, accounting as well for the potential endogeneity in the relations examined, confirm the important role played by returnees in the recent globalization of the Chinese economy while distinguish the different effects of returnees serving different business functions. We found that it is mainly those individuals in the most strategic functions who have significant effect on both the propensity and the level of overseas direct investment. Firms that are less experienced in international operation benefits more from returnees. Our findings have important implications for policy makers and practitioners as they could indicate to what extent and in what ways inexperienced Chinese MNEs can obtain knowledge and capabilities in international operation more quickly by attracting highly skilled returnees.

The remainder of the paper is structured as follows. Section 2 develops the research hypotheses and discusses their theoretical underpinnings. Section 3 introduces the data and the empirical specification. Section 4 discusses the results, while Section 5 concludes. 


\section{Theory and Hypotheses}

Skilled migrants can contribute to their home country's development in a variety of ways, in particular as sources of human capital, productivity, finance, technology and knowledge flows back home (Docquer and Rapoport, 2012). Recently, emphasis has been given to the concept of circular migration of skilled professionals, which sees the returnees as transnational agents with a specific ability to operate in different environments, identifying market opportunities and managing cross-border operations (Saxenian, 2006). In some emerging economies, such as Taiwan and India, the return of highly skilled migrants has often resulted in the creation of dynamic high technology industries (Agrawal et al., 2011; Kenney et al., 2013). Along the lines of the existing literature on the topic (Dai and Liu, 2009; Liu et al., 2010, 2014; Cui et al., 2013, 2014) in this paper we combine the knowledge based view of the firm with the organizational learning perspective to understand how firms acquire the knowledge necessary to compensate for the latecomer disadvantages and to internationalize through FDI.

\subsection{Returnees and firms' capability augmentation: the knowledge based view}

\subsubsection{Returnees as knowledge source}

Following the knowledge based view (Kogut and Zander, 1993), the possession of adequate knowledge of foreign markets and the organizational capacities to deal with different contexts and cultures informs the foreign entry decision of firms (Lu et al., 2014). The KBV assumes that knowledge is the most valuable source of a firm's competitive advantage. Central to this approach is the idea that knowledge can take different forms, tacit or explicit, and can be sourced both internally and externally to the firm. Experiential drivers acquired through organizational learning and the presence of returnees can be viewed as the two major sources of the specific knowledge of foreign markets that influence the decision to invest overseas (Cui et al., 2013).

Returnees represent a key source of knowledge and network-based resources due to their acquired skills and confidence with world-class technologies and overseas markets, and we can therefore argue that their presence contributes to increase the probability of firms to invest abroad (Gao et al., 2013). Given the tacit nature of such knowledge it is possible to identify different ways through which the background of the returnees can influence firms' OFDI decisions. Due to their "dual orientation", returnees help to bridge the cultural gap with overseas markets, reducing psychic distance, and the likely risks and high transaction costs associated with the decision to invest abroad (Rabbiosi and Stucchi, 2012). Thanks to their work and education experiences, returnees have developed personal and professional networks that contribute to their ability to manage operations across borders (Cui et al., 2013). As a matter of fact, most of the Chinese returnees who are involved in business activities affirm that they have kept a strong overseas network (Wang et al., 2011), especially with local ethnic organizations, as in the case of the US (Wadhwa et al., 2011). Lastly, 
previous research has demonstrated that in the absence of local ties, they can have stronger incentives to pursue a firm's efficiency and profitability rather than searching for political connections (Giannetti et al., 2015).

Even if it could be claimed that the international background of returnees is worth in itself, it is also important to state that not all the returnees employed by Chinese firms might be equally involved in activities directly related to their internationalization via OFDI. According to the KBV, previous foreign experience of individuals at the decision making level may shape a firm's internationalization strategy (Filatotchev et al., 2009). Still, related evidence shows that even practical experience acquired in technical functions may be equally important (Saxenian, 2006).

\subsubsection{Returnees' functional role and the internationalization of EMNEs}

An interesting piece of evidence that we are able to provide in this paper is about the role of top management (CEOs) and the dominant coalitions in firms' overseas investment decision. We are also able to make an important distinction between returnee CEOs and returnees serving the various management functions in a firm. In doing this, even if limited by the lack of more detailed information on the decision making process, we can also dig into strategic choice analysis and draw some approximation on how different power-holders within a firm decide on a strategic action (Child, 1972; 1997). This is an important distinction in the context of emerging markets, as some early evidence has shown that different modes of corporate governance and the composition of corporate boards of firms have direct influence on their FDI decisions (Lien et al., 2005; Filatotchev et al., 2007). And, though the evidence is still scant, this has been found to be relevant also in the context of China. As shown by a recent work combining a corporate governance view with agency theory, the different degree of power a CEO holds along the different organizational forms is found to influence directly the internationalization decision (Hu and Cui, 2014). Similarly, the role of outside or independent management, including returnees, has a positive impact on corporate governance practices and firms' performance, by reducing agency and raising shareholder protection (Shapiro et al., 2015; Cui et al., 2014; Giannetti et al., 2015).

While there is much anecdotal evidence of successful internationalization by Chinese companies led by a CEO with international experience (Wang, 2012; Cui et al., 2014), less has been said on the role of returnees in managerial positions. As suggested by Chen et al. (2015) returnee managers differ from returnee entrepreneurs in terms of the potential of knowledge transfer to the firm given the challenge for the managers to enter in an already existing organizational context. Existing literature has put some emphasis on the role of managers as a source of firm-specific ownership advantages, including in the context of emerging economies (Yiu et al., 2007), showing that previous experience in working and studying abroad by managers represents a key asset that can ease foreign investment decisions (Tan and Meyer, 2010; Boermans and Roelfsema, 2013). This has been attributed to the managers' global mind-set, which facilitates the recognition of opportunities abroad and reduces their cognitive 
bias towards the host country market (Tan and Meyer, 2010; Cui et al., 2013). Evidence exists also in the context of China. Cui et al. (2013), use a sample of listed firms in the electronics industry to show that the presence in the top management of individuals with foreign experience has a positive impact on a firm's FDI decision ${ }^{2}$. Returnees in managerial positions are also the focus of the study by Cui et al. (2014), again on Chinese electronic manufacturing firms. Interestingly, their paper concludes that the potential contribution of returnee managers is affected by the corporate governance of the firm, and is stronger for private companies and SOEs owned by central government than for those owned by local governments. ${ }^{3}$

H1a: Chinese firms whose $C E O$ and/or managers have international experience are more likely to be engaged in OFDI.

It is unlikely that foreign experiences will guarantee everyone the opportunity to be involved in the managerial positions, while it is also true that not only returnees in high-level positions will influence the firm's strategic investment decision. The foreign experience of returnees can compensate for the shortage of qualified skills in the home country and bring international knowledge and operational experience to other functions than those directly related to strategic management. Experienced returnees can facilitate, for instance, the introduction of superior business practices, similar to those that give firms in more advanced economies a competitive edge (Fu, 2012), or specific technical knowledge that they have acquired through education, training or direct work experience (Dai and Liu, 2009). In addition, returnees may have acquired practical business knowledge from working in commercial activities, thus allowing them to understand the complexities of global operations, the characteristics of foreign markets, and the business climate as well as cultural patterns (Saxenian, 2006). Some of these features increase the ownership advantages of domestic firms and reduce the distance to foreign markets. Hence, besides testing the implications of having returnees in the top management of firms, we also control for the implication of exploiting their knowledge and skills for other functions, which can indirectly relate to the choice of embarking on FDI.

H1b: Chinese firms whose returnees are employed in strategic functions not directly related to management, including $R \& D$ and commercial services, are also more likely to be engaged in OFDI.

\footnotetext{
2 The authors conclude that having managers with previous international working experience is more effective than having managers with foreign study experience only, given that the kind of knowledge involved with the FDI decision is more relevant if acquired in a work rather than only in an educational context.

${ }^{3}$ A related work is the one by Giannetti et al. (2015), which explores the impact of returnees in the board of directors on the performance, including foreign, of Chinese listed firms. They show in particular that, besides improving their productivity and other indicators of performance, firms managed by returnees are more likely to undertake foreign M\&As.
} 


\subsection{The role of returnees in Latecomer EMNEs: an organizational perspective}

Following the organizational learning perspective, the process of internationalization strongly relies on knowledge of foreign markets and accumulated prior experience with foreign business operations (Johanson and Vahlne, 1977). In addition, nowadays, with a changed global landscape, international operations of MNEs demand a range of complex tasks including managing international supply chains, production, marketing and knowledge flows. All in all, this requires time for firms to accumulate strong capabilities in international management.

However, most EMNEs, including Chinese, go global without well-developed capabilities in international operations and management (Luo and Tung, 2007), some pushed by government policy or fierce domestic competition ( $\mathrm{Lu}$, et al., 2011). These EMNEs are often 'infant', which means that they do not possess the ownership advantages in management and technology as compared to traditional multinationals. Research on the rise of EMNEs has stressed that this can be linked to their role of latecomers in international markets, and the subsequent need to reduce the timing of entry into global markets to get access to the resources they lack (Mathews, 2002). The need to rapidly catch-up to acquire resources to upgrade and become more competitive internationally can therefore create a tension between an exploitation strategy based on organizational experience, and an exploration strategy to catch new opportunities mostly dealing on managerial international experience (Cui et al., 2013).

This seems especially true in a context as peculiar as the Chinese one. ${ }^{4}$ In some cases, the lack of prior international experience of many Chinese firms and their cultural distance from western companies have led observers to raise concerns about their ability to successfully manage large scale operations abroad (Buckley et al., 2008; Nolan, 2012). This is supported by existing evidence on some complicated post-M\&As (Rugman and Li, 2007; Spigarelli et al., 2013). The shortage of domestic "talents" with relevant international experience is often advocated as one of the main constraints to the performance of Chinese firms and their globalization strategies (Rugman and Li, 2007; Giannetti et al., 2015) ${ }^{5}$.

Latecomer Chinese firms can therefore find innovative approaches to acquire knowledge of foreign markets, in contrast with the experiential learning hypothesis. Hiring returnees, with the stock of international experiences that they gained from their overseas study and working experiences, can be seen as

\footnotetext{
4 The emergence of OFDI from China is regarded to take place within the context of global commodity chains with an embedded power structure (Gereffi, 1999) and within the systematic organization of the "global factory" (Buckley, 2009). Firms controlling activities in the middle of the value chain have strong incentives to move to the two ends of the value chain so as to acquire the resources and competencies that will enable them to control higher value-added activities and implement catch-up processes (Buckley, 2009).

${ }^{5}$ In a recent survey of 110 executives from Chinese companies, $82 \%$ of them identified the lack of management expertise in handling OFDI the main challenge for future investments abroad (EIU, 2010).
} 
an alternative strategy that is especially relevant for latecomer and recently born Chinese MNEs (Cui et al., 2014). In addition, it has been claimed that returnees can provide Chinese firms lacking foreign experience with the international legitimacy that they have acquired during their previous experiences, and their capacity to market products and services internationally thanks to their connections (Wang et al., 2011). Therefore, experienced returnees can compensate for the shortage in international operations, accelerate the acquisition of knowledge of international markets and affect their propensity to undertake OFDI.

H2: Returnees can compensate for the lack of experience in latecomer firms and bring the knowledge necessary to engage in OFDIs.

\section{Data and empirical model}

\subsection{Data}

We empirically test our research hypotheses using a sample of firms from Guangdong Province of China, which is located on the shore of the South China Sea, adjacent to the Hong Kong Special Administrative Region. It contributes for a large proportion of China's total economic output, approximately $11 \%$ in 2015. Combining a well-developed infrastructure, strong policy incentives, and rich human resource advantages, Guangdong province has attracted a large share of Chinese returnees since the 1990s. With the acceleration of industrial restructuring and upgrading in 2008, Guangdong province, especially the Pearl River Delta cities, strengthened the promotion of a business incubator for returnees and introduced many investment policy packages to attract talents, including the high level of venture capital funding, start-up facilities, housing benefits, etc. (Guangdong Provincial Party Committee, 2015). The total number of returnees grew rapidly and reached 30 thousand by 2012. A series of policy incentives has been issued to attract foreign talents such as the RMB 1 billion investment plan to encourage innovation and entrepreneurship of returnees during the period 2010-2020.6 In addition, as the province that first opened up to international trade and investment, Guangdong also witnessed increasing internationalization of its firms. The amount of outward overseas investment from Guangdong is the largest of all provinces in China. Guangdong's nonfinancial overseas investment in 2014 accounted for $6.64 \%$ of the stock of China's OFDI, reaching 49.48 USD billion.

The firm-level data used in the empirical analysis come from a purposely designed survey on the determinants and impacts of Chinese firms' outward direct investment, which was carried out by a collaborative research team of British and Chinese universities in Guangdong province in 2010.7 Guangdong

6 Data source: Guangdong Human Resource and Social Security Bureau. http://www.gdhrss.gov.cn/

7 The implementation of the survey received tremendous support from Guangdong Commission of Foreign Trade \& Economic Cooperation as well as the Guangdong Research Institute for International Strategies. 
provides an ideal research setting for the objectives of this research. Not only is it the region with the largest amount of OFDI and a high number of returnees, but also it gives us an opportunity to understand the motivation, behavior and impact on the OFDI by firms in China's first opened up and most market-oriented region.

Because the survey collects many objective information on a firm's financial, investment, export performance and management characteristics, a postal survey is more appropriate than a face-to-face interview. Therefore, a postal survey instrument was employed given the nature of the questionnaire, the capabilities of the respondents, the culture in the region, and the financial budget available. Given the fact that there was only a small proportion of Chinese firms that have invested abroad, and that even in Guangdong they are highly concentrated in the Pearl River Delta, the survey sampling focused on the firms in this region and over sampled the group of internationalized firms. Therefore, the sampling framework of the survey was drawn from firms that had overseas direct investment or were regarded as having the potential to go global. The latter group of firms has been selected mainly based on their financial and growth performance, outward orientation, and their interest in OFDI as indicated to the local committees of foreign trade. A list was created of 2,000 firms meeting these criteria in all industries in the Pearl River Delta. Questionnaires were posted to the CEO or deputy CEO in charge of strategy or marketing in these 2,000 firms in 2010 after a preliminary piloting with 10 of them. Given the time that was needed to complete this complex questionnaire, three months were given to the return of the completed questionnaires. Postal and telephone prompts were made to increase the response rate. In the end, 341 valid responses were received, with a response rate of about $17 \%$.

The questionnaire includes three sections asking firms to provide information on (1) basic characteristics and past export activities and destinations; (2) their motivation, mode, destination and investment scale of OFDI and the challenges faced; and (3) their innovation, human resources and management characteristics. Each firm was asked to provide detailed information on their performance in the global market, such as exports and overseas investment experience, their motivations in this endeavor and the impacts and challenges observed so far. The questionnaire also asked firms for information on the nature of their business and other characteristics such as ownership, management, innovation activity, strategic orientation, industry, scale, and labor skills such as educational attainment of the employees and top managers. In addition, the survey covers a number of questions with reference to the number of returnees in each firm and their corresponding positions in the firm. ${ }^{8}$

Among the 341 respondents, 299 were non-state owned and 26 were state owned enterprises (SOEs). It was not possible to identify the ownership of the remaining 16 firms. 328 firms provided information on their registered

\footnotetext{
8 The survey researchers also interviewed senior managers and business owners of 21 firms to cross check the questionnaire response and to gain further qualitative insights concerning the motivation and impact of overseas investment.
} 
industry/trade, including 267 manufacturing firms, 23 enterprises involved in wholesale and retail, 9 IT service companies and 29 in other industries. After a further cleansing of the data and having accounted for missing information, the final sample consists of 160 firms across 25 industries. ${ }^{9}$

\subsection{The Model}

Our dependent variable, Outward FDI (OFDI), is measured in two ways. First, it is denoted as a dummy variable taking the value of 1 if a firm has reported a positive value in 2009. Once the investment decision is made, the firm will plan the amount of investment abroad. Therefore, the second measure for OFDI is the level, i.e. the total value actually invested abroad. Both the decision and the level of OFDI are determined by several factors, as reported below:

$$
\begin{aligned}
& \text { OFDI }_{i}^{*}=\alpha+\beta \text { Re } \text { turnees }_{i}+\beta_{a} \text { Age }_{i}+\beta_{e} \text { Export }_{i}+\beta_{e} \text { Edu }_{i}+\beta_{s} \text { Size }_{i}+\beta_{\text {soe }} S_{\text {SOE }}+\beta_{\text {ind }} \text { Ind }+\varepsilon_{i} \\
& \text { OFDI }_{i}=\left\{\begin{array}{cl}
O F D I_{i}^{*} & \text { if } \quad \text { OFDI }_{i}^{*}>0 \\
0 & \text { otherwise }
\end{array}\right.
\end{aligned}
$$

Where the level of OFDI is only observed when a firm has decided to conduct cross border investment. A zero value is assigned to OFDI if the latent variable OFDI* is non-positive. As reported in equation (1), the set of independent variables include factors representing knowledge acquisition that have the potential to affect the OFDI status of firms.

Specifically, this study includes two variables measuring organizational experience. The first is the age $(A G E)$, which represents the overall experience of a firm, measured as the number of years since its establishment. Empirical investigations of the models of heterogeneous firms consistently show that firms with a longer life are more actively performing and more likely to invest abroad (Helpman et al., 2004). On the other hand, literature on both born global firms and latecomer EMNEs shows that due to market pressures, firms might invest at earlier stages of their development (Ramamurti, 2009; Mathews, 2002). The second variable measures a firm's experience with the international markets (EXPORT), which is measured by the number of years since the firm started exporting. If a firm follows a sequential internationalization pattern like the one predicted by Johanson and Vahlne (1977), then one should expect the experience built by exporting to influence OFDI decisions.

We also account for the size (SIZE) of firms, measured with the number of employees, expecting a positive impact on OFDI, and for the presence of State Ownership (SOE), which is an important feature affecting the structure of

\footnotetext{
${ }^{9}$ Removing observations with missing values will inevitable cause bias. Yet our sample with 160 observations is in general consistent with the original sample of 341 firms after comparing the summary statistics. This is the case of key variables, including size, education of the workforce or the proportion of SOEs, both reporting close average values between the original and the cleaned sample. Some differences are found in terms of firms' age and export. Therefore, the interpretation of estimation results in the following section should also take into account this potential bias.
} 
Chinese companies. In addition, a set of industry dummies (IND) are included as well to control for industry idiosyncratic effects, including for instance the presence of incentives to internationalization to targeted industries or the existence of comparative advantages.

Finally, we control also for the level of education of the employees $(E D U)$, to account for the presence of a skilled workforce and their effect on firm's globalization. The quality of human capital influences the learning infrastructure at firm-level (Meyer and Sinani, 2009; Farole and Winkler, 2012). Formal education and training enable employees to understand the technological development, as well as affect the effectiveness of international learning (Nelson and Phelps, 1966). In the context of the KBV, we can also consider this variable as one of the knowledge infrastructure proxy (together with the technological capacity and training), i.e. internal capability to ensure firms' international competitiveness and support global expansion activities (Meyer and Sinani, 2009), and to absorb and integrate knowledge transferred by returnees and internationalization activities (Cohen and Levinthal 1990).

This work specifically accounts for the number and status of the returnees employed by each firm. On this respect, we can exploit the richness of the information provided in the survey, which allows us to improve on the existing literature, so far considering returnees either independently on their functions (Gao et al., 2013) or explicitly focusing only on those at the top management level (Cui et al., 2013, 2015).

Thanks to our data, we are able to decompose the group of workers with foreign experiences into a set of variables that captures various characteristics of returnees. First, the variable "RRatio" is a more general indicator of the relative size of the returnees' component for each firm, indicating their share in the total number of employees within each firm, irrespective of their role.

Following discussion in section 2, we are also interested in understanding whether having returnees employed in more strategic functions has an implication for the propensity to undertake OFDI. To do this, this study takes advantage of a unique aspect of the survey, which not only is able to identify firms directly managed by a CEO with international background, but also provides detailed information on the department in which returnees are employed. So, the variable "CEO" takes the value of 1 if the top manager has at least half a year training or education experiences outside of China. The variables "RManage", "RR\&D", "RSales" represent three different business functions in which a returnee can be involved, including management; R\&D or innovation; and market or sales related-functions. We also add a residual variable, "ROther", covering the returnees involved in functions not elsewhere specified, including for instance finance and human resource management.

Table 1 and Figure 1 report some simple statistics on the variables used in the empirical model. More than one third of the sample firms have reported at least an overseas investment. Concerning returnees, descriptive statistics show that on average - they account for a very small fraction of a firm's total employment. 
Only $0.4 \%$ of workers in the sample had some overseas experiences. Numbers become significant once we distinguish returnees according to their role within firms. In general, employees with foreign experiences are more likely to participate in managerial level positions. About 29\% of CEOs of firms included in our sample have gained experiences or knowledge from a foreign country, whereas $18 \%$ of firms reported to have returnees as managers or involved in management related position. Returnees involved in other functions, and especially in sales and $R \& D$, are also present in sample firms, though less frequently.

Table 1. Summary of variables

\begin{tabular}{|c|c|c|c|c|c|}
\hline Variable & Definition & Mean & Std. Dev. & Min & Max \\
\hline OFDI & $\begin{array}{l}\text { Total outward foreign } \text { direct } \\
\text { investment in 2009, in log }\end{array}$ & 1.19 & 2.17 & 0 & 8.49 \\
\hline Age & $\begin{array}{l}\text { Number of years since the firm was } \\
\text { established, in log }\end{array}$ & 2.61 & 0.48 & 1.39 & 4.08 \\
\hline Export & $\begin{array}{l}\text { Number of years that a firm has } \\
\text { participated in export activities, in } \\
\text { log }\end{array}$ & 0.71 & 0.35 & -0.37 & 1.39 \\
\hline Edu & $\begin{array}{l}\text { The proportion of employees that } \\
\text { have completed at least the } \\
\text { undergraduate degree, } \%\end{array}$ & 24.45 & 21.77 & 0.76 & 100 \\
\hline Size & $\begin{array}{l}\text { Total number of employees in } 2009 \text {, } \\
\text { in log }\end{array}$ & 5.88 & 1.51 & 1.10 & 9.61 \\
\hline SOE & $\begin{array}{l}\text { Value } 1 \text { if a firm is a State-owned } \\
\text { enterprise, dummy }\end{array}$ & 0.08 & 0.27 & 0 & 1 \\
\hline RRatio & $\begin{array}{l}\text { Ratio of returnees in the total } \\
\text { number of employees, } \%\end{array}$ & 0.41 & 1.59 & 0 & 14.29 \\
\hline RManage & $\begin{array}{l}\text { Value } 1 \text { if any returnee takes } \\
\text { management position, dummy }\end{array}$ & 0.18 & 0.38 & 0 & 1 \\
\hline RR\&D & $\begin{array}{l}\text { Value } 1 \text { if any returnee works in the } \\
\text { R\&D department, dummy }\end{array}$ & 0.08 & 0.27 & 0 & 1 \\
\hline RSale & $\begin{array}{l}\text { Value } 1 \text { if any returnee works in } \\
\text { sales or market department, } \\
\text { dummy }\end{array}$ & 0.09 & 0.28 & 0 & 1 \\
\hline ROther & $\begin{array}{l}\text { Value } 1 \text { if any returnee has involved } \\
\text { in other position, dummy }\end{array}$ & 0.01 & 0.11 & 0 & 1 \\
\hline
\end{tabular}


Figure 1. The distribution of firms by OFDI, ownership and returnees presence

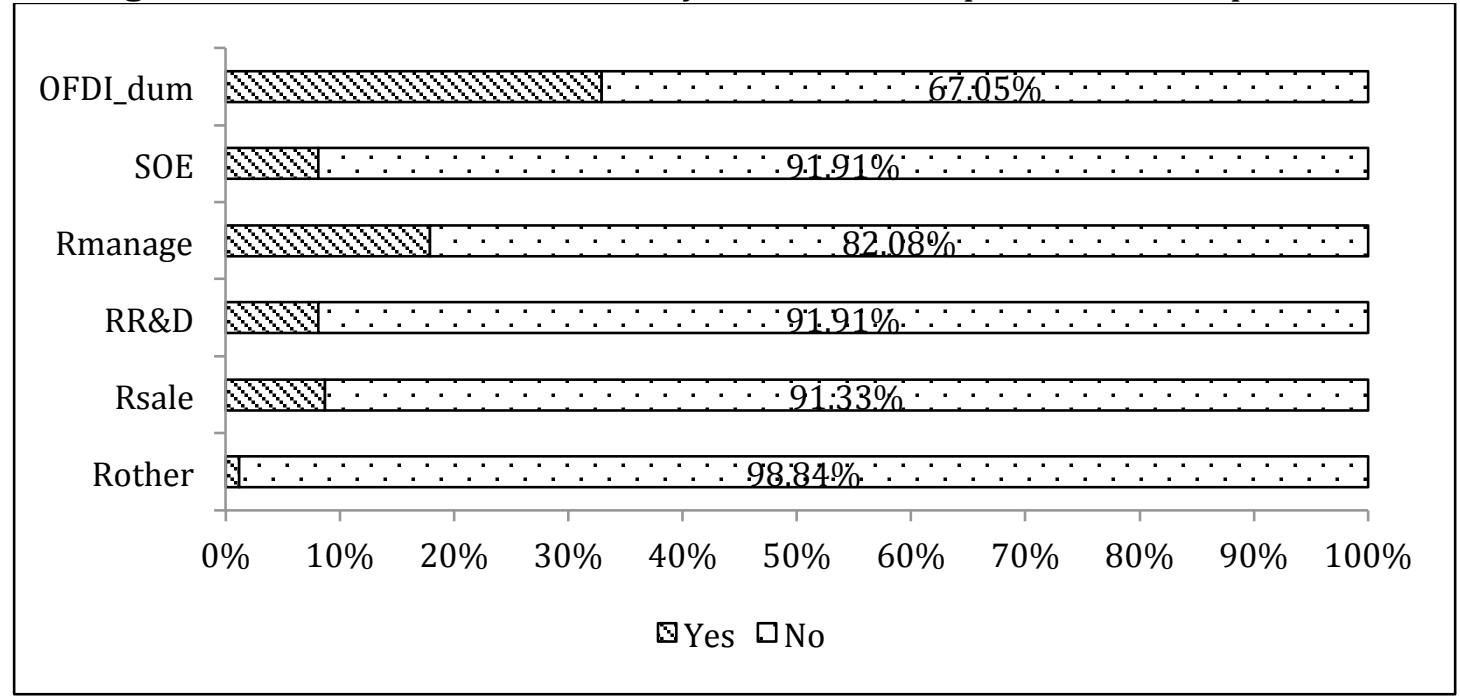

Source: Authors' elaboration on survey data.

Preliminary evidence on the association between the likelihood of undertaking outward FDI and the presence of returnees is presented in Table 2. Although both OFDI and non-OFDI firms employ workers with an international background, the presence of returnees in firms with cross-border investment activities is significantly higher compared to those without. A simple T-test on the mean differences shows in fact that not only OFDI firms are more likely to be owned by a CEO with international experience, but also that they employ relatively more returnees involved in other positions.

Table 2. Descriptive statistics between OFDI and Non-OFDI, mean values

\begin{tabular}{l|cccccc}
\hline & CEO & RRatio & RManage & RR\&D & RSale & ROther \\
\hline OFDI $=0$ & 0.241 & 0.272 & 0.121 & 0.052 & 0.060 & 0.009 \\
OFDI = & 0.404 & 0.678 & 0.298 & 0.140 & 0.140 & 0.018 \\
\hline T-test: & & & & & & \\
OFDI(0) -OFDI(1) & $-2.22^{* *}$ & -1.58 & $-2.91^{* * *}$ & $-2.02^{* *}$ & $-1.76^{*}$ & -0.51 \\
\hline Total & 0.295 & 0.406 & 0.179 & 0.081 & 0.087 & 0.012 \\
\hline
\end{tabular}

\section{Empirical Analysis}

\subsection{First stage results: what determines the probability to invest?}

Given the non-negative nature of OFDI, a Tobit model is more appropriate than an Ordinary Least Squared method since it controls for the potential selection bias caused by the left censored dependent variable. Table 3 reports the result of the first stage testing the impact of the dependent variables, including those related to the returnees, on the probability of a Chinese firm's decision to undertake OFDI. The marginal effects of estimated coefficients are presented and robust standard errors reported in parentheses. We start by discussing the results of the control variables, to move then to our variables of interest. 
We confirm that there is in general a positive and statistically significant relation between the age of a firm and its propensity to undertake OFDI, meaning that the overall experience and the stock of knowledge acquired by firms in their daily operations matters. This finding is quite relevant in the context of an emerging economy like China which hosts a large number of recently established firms, especially private and in the high-tech industry. For these firms acquiring the necessary resources, such as knowledge of foreign markets and international networking, may be difficult and may represent a high barrier to entry. Conversely, sampled firms do not take advantage of experiential learning through other, lighter, forms of internationalization. The coefficient measuring export years is in fact negative, though not significant. A possible explanation for this is that exporting only partly captures the previous international experiences of a firm and that exports and FDI might not necessarily complement each other. Moreover, OFDI not motivated by market oriented strategies, might not be directly affected by previous experience of serving foreign markets through exports.

On the other hand, we show that FDI is positively correlated with the size of firms. In general, large-scale firms are characterized by larger financial and other tangible resources, which represent some of their key ownership advantages that can be exploited abroad (Buckley et al., 2014).

Moving to the influence of the quality of workers, or the stock of human capital held by a firm, we find that OFDI decisions are positively related to the overall level of education of the workforce. This suggests that firms with higher levels of human capital in the form of a large number of highly educated employees are more ready to invest overseas. They also enjoy greater absorptive capacity to absorb and integrate the knowledge spillover arising from internationalization process. ${ }^{10}$

Interestingly, we find a strongly negative and statistically significant relation between state ownership and the probability of conducing OFDI. This result is consistent with recent evidence by $\mathrm{Hu}$ and Cui (2014), one of the first works to bring a corporate governance perspective to the study of China's OFDI. Although SOEs can enjoy financial support and other incentives, the authors attribute such negative performance to the lengthy procedures they need to comply with before investing, and the high levels of scrutiny they are subject to from host governments, due to national interest concerns (Hu and Cui, 2014). In addition, there is an issue related to productivity. Due to inherited inefficiencies from the central-planned economy era, Chinese state-owned enterprises are still hindered by their inefficient management practices and excess of unskilled workers, and only a few of them, especially in the construction, extractive sectors, can successfully go out.

\footnotetext{
10 Interestingly, if we try to interact the education variable with our returnees' variables we do not find evidence of a self-reinforcing relation, but rather of a substitution effect (results, not reported for reasons of space, are available upon request to the authors). This seems to reinforce our hypothesis 2 , in that returnees are currently seen mostly as a main source of experience and knowledge for firms that lack both or have insufficient capacities to absorb new resources.
} 
Table 3. Tobit first stage results: using OFDI dummy as dependent variable, marginal effects

\begin{tabular}{|c|c|c|c|c|c|c|c|}
\hline VARIABLES & $\begin{array}{c}(1) \\
\text { RRatio }\end{array}$ & $\begin{array}{c}(2) \\
\text { CEO } \\
\end{array}$ & $\begin{array}{c}\text { (3) } \\
\text { RManag }\end{array}$ & $\begin{array}{c}(4) \\
\text { RR\&D }\end{array}$ & $\begin{array}{c}(5) \\
\text { RSale } \\
\end{array}$ & $\begin{array}{c}(6) \\
\text { ROther }\end{array}$ & $\begin{array}{l}\text { (7) } \\
\text { Full } \\
\end{array}$ \\
\hline Age & $\begin{array}{c}0.173^{*} \\
(0.089)\end{array}$ & $\begin{array}{c}0.171^{*} \\
(0.089)\end{array}$ & $\begin{array}{c}0.164^{*} \\
(0.090)\end{array}$ & $\begin{array}{c}0.165^{*} \\
(0.091)\end{array}$ & $\begin{array}{l}0.189 * * \\
(0.089)\end{array}$ & $\begin{array}{c}0.151^{*} \\
(0.091)\end{array}$ & $\begin{array}{l}0.214^{* *} \\
(0.088)\end{array}$ \\
\hline Export & $\begin{array}{l}-0.144 \\
(0.111)\end{array}$ & $\begin{array}{c}-0.140 \\
(0.112)\end{array}$ & $\begin{array}{c}-0.150 \\
(0.113)\end{array}$ & $\begin{array}{c}-0.139 \\
(0.113)\end{array}$ & $\begin{array}{c}-0.147 \\
(0.112)\end{array}$ & $\begin{array}{c}-0.108 \\
(0.113)\end{array}$ & $\begin{array}{l}-0.183^{*} \\
(0.109)\end{array}$ \\
\hline Edu & $\begin{array}{c}0.006^{* * *} \\
(0.002)\end{array}$ & $\begin{array}{l}0.005^{* *} \\
(0.002)\end{array}$ & $\begin{array}{l}0.005^{* *} \\
(0.002)\end{array}$ & $\begin{array}{l}0.006^{* *} \\
(0.002)\end{array}$ & $\begin{array}{c}0.006^{* * *} \\
(0.002)\end{array}$ & $\begin{array}{c}0.006^{* * *} \\
(0.002)\end{array}$ & $\begin{array}{l}0.005^{* *} \\
(0.002)\end{array}$ \\
\hline Size & $\begin{array}{c}0.095^{* * *} \\
(0.029)\end{array}$ & $\begin{array}{c}0.079^{* * *} \\
(0.028)\end{array}$ & $\begin{array}{c}0.077^{* * *} \\
(0.029)\end{array}$ & $\begin{array}{c}0.079 * * * \\
(0.029)\end{array}$ & $\begin{array}{l}0.074^{* *} \\
(0.030)\end{array}$ & $\begin{array}{c}0.082^{* * * *} \\
(0.030)\end{array}$ & $\begin{array}{c}0.086^{* * *} \\
(0.030)\end{array}$ \\
\hline SOE & $\begin{array}{c}-0.242^{* * *} \\
(0.081)\end{array}$ & $\begin{array}{l}-0.181^{*} \\
(0.101)\end{array}$ & $\begin{array}{c}-0.207^{* *} \\
(0.091)\end{array}$ & $\begin{array}{c}-0.205^{* *} \\
(0.092)\end{array}$ & $\begin{array}{c}-0.195^{* *} \\
(0.095)\end{array}$ & $\begin{array}{l}-0.182^{*} \\
(0.104)\end{array}$ & $\begin{array}{c}-0.245^{* * *} \\
(0.079)\end{array}$ \\
\hline RRatio & $\begin{array}{l}0.049^{* *} \\
(0.023)\end{array}$ & & & & & & $\begin{array}{c}0.029 \\
(0.026)\end{array}$ \\
\hline CEO & & $\begin{array}{l}0.181^{* *} \\
(0.082)\end{array}$ & & & & & $\begin{array}{c}0.138 \\
(0.085)\end{array}$ \\
\hline RManag & & & $\begin{array}{l}0.228^{* *} \\
(0.103)\end{array}$ & & & & $\begin{array}{c}0.079 \\
(0.116)\end{array}$ \\
\hline RR\&D & & & & $\begin{array}{c}0.238 \\
(0.148)\end{array}$ & & & $\begin{array}{c}0.010 \\
(0.152)\end{array}$ \\
\hline RSale & & & & & $\begin{array}{l}0.285 * * \\
(0.137)\end{array}$ & & $\begin{array}{c}0.198 \\
(0.160)\end{array}$ \\
\hline ROther & & & & & & $\begin{array}{c}0.015 \\
(0.304)\end{array}$ & $\begin{array}{c}-0.256^{* *} \\
(0.126)\end{array}$ \\
\hline Industry effects & Yes & Yes & Yes & Yes & Yes & Yes & Yes \\
\hline Observations & 160 & 160 & 160 & 160 & 160 & 160 & 160 \\
\hline
\end{tabular}

Robust standard errors in parentheses,

${ }^{* * *} \mathrm{p}<0.01,{ }^{* *} \mathrm{p}<0.05,{ }^{*} \mathrm{p}<0.1$.

Moving to the main variables of interest, columns (1) - (6) report the estimates by including the different returnees' indicators individually, as described in equation (2). ${ }^{11}$

Overall, results in column (1) show that the mobility of high skilled human capital, especially of those individuals with international background, contributes to emerging economies' internationalization and development. More specifically, we find a robust relation between the relative share of returnees of a firm and the probability of being involved in OFDI (Column 1). This result follows our prior expectations, and it is as well coherent to some existing literature, which has showed so far similar results in the context of other emerging markets (such as India, Boermans and Roelfsema, 2013), as well as China (Gao et al., 2013; Chen and Fang, 2016). This first result confirms the view that owing to their strong knowledge and understanding of foreign markets, returnees play the role of transnational agents that identify and manage crossborder activities.

Not all the returnees employed by Chinese companies are equally involved with the process leading to overseas investments. Indeed, the results add that individuals with international experience who are involved at more strategic

\footnotetext{
11 We add the returnees' variable individually due to their high correlation. Indeed, column (7) reporting results for all such variables together show that they hardly get to be significant.
} 
levels have a stronger potential to shape firms' internationalization practices. Not only does the study show that firms whose CEOs are returnees have a larger probability to invest overseas (Column 2), but also that having returnees in more general management functions is positively affecting OFDI choices (Column 3). Taken together, these results confirm the relevant role that returnees in the top management hold in Chinese companies, especially as key sources of knowledge on foreign markets as well as through their international networks (hp. 1a). In contrast to other studies that have investigated separately the role of CEO returnees (Wang et al., 2011) or returnees in the management (Cui et al., 2013), our results show that both play a significant and possibly complementary role, accounting thus to some extent for the potential power asymmetries in a company's board (Hu and Cui, 2014).

Lastly, along the lines of hypothesis $1 \mathrm{~b}$, it is particularly interesting to observe that the presence of returnees in the sales department has a positive and significant impact on the probability of undertaking an overseas investment (Column 5). The presence of individuals with a deep knowledge of foreign markets and with international networks taking care of foreign sales strategies of the firms can be considered a relevant support to the strategic decision to undertake OFDI. Though positive, we do not find significant relations between the involvement of returnees in R\&D and FDI. A possible explanation for this is that returnees are mostly needed to foster the development of in-house innovation capacities, as documented for instance by Liu et al. (2010) and Luo et al. (2013), rather than as a source of knowledge to explore foreign markets.

\subsection{Second stage: The role of returnees on investment size}

In order to investigate whether the presence of returnees has an influence also on the intensity of the investment, Table 4 reports the results of the second stage of the Tobit procedures, which describes the determinants of the OFDI level. The 0.01 significance level of sigma implies that the censored nature of OFDI would lead to biased results if we apply a linear ordinary least square approach. 
Table 4. Tobit second stage results: using OFDI logarithm as dependent variable, marginal effects

\begin{tabular}{|c|c|c|c|c|c|c|c|}
\hline VARIABLES & $\begin{array}{c}\text { (1) } \\
\text { RRatio }\end{array}$ & $\begin{array}{l}(2) \\
\text { CEO } \\
\end{array}$ & $\begin{array}{c}3) \\
\text { RManag }\end{array}$ & $\begin{array}{c}4) \\
\text { RR\&D }\end{array}$ & $\begin{array}{c}(5) \\
\text { RSale }\end{array}$ & $\begin{array}{c}6) \\
\text { ROther }\end{array}$ & $\begin{array}{l}7) \\
\text { Full }\end{array}$ \\
\hline Age & $\begin{array}{c}2.419^{*} \\
(1.441)\end{array}$ & $\begin{array}{c}2.360 \\
(1.466)\end{array}$ & $\begin{array}{c}2.220 \\
(1.404)\end{array}$ & $\begin{array}{c}2.309 \\
(1.467)\end{array}$ & $\begin{array}{c}2.502^{*} \\
(1.451)\end{array}$ & $\begin{array}{c}2.050 \\
(1.436)\end{array}$ & $\begin{array}{l}2.808^{* *} \\
(1.402)\end{array}$ \\
\hline Export & $\begin{array}{l}-1.251 \\
(1.745)\end{array}$ & $\begin{array}{l}-1.196 \\
(1.772)\end{array}$ & $\begin{array}{c}-1.749 \\
(1.734)\end{array}$ & $\begin{array}{c}-1.071 \\
(1.769)\end{array}$ & $\begin{array}{c}-1.338 \\
(1.773)\end{array}$ & $\begin{array}{c}-0.566 \\
(1.736)\end{array}$ & $\begin{array}{l}-1.979 \\
(1.700)\end{array}$ \\
\hline Edu & $\begin{array}{c}0.116^{* * *} \\
(0.034)\end{array}$ & $\begin{array}{c}0.114^{* * *} \\
(0.035)\end{array}$ & $\begin{array}{c}0.104^{* * *} \\
(0.034)\end{array}$ & $\begin{array}{c}0.117^{* * *} \\
(0.035)\end{array}$ & $\begin{array}{c}0.121^{* * *} \\
(0.034)\end{array}$ & $\begin{array}{c}0.123^{* * *} \\
(0.035)\end{array}$ & $\begin{array}{c}0.097^{* * *} \\
(0.033)\end{array}$ \\
\hline Size & $\begin{array}{l}1.241^{* *} \\
(0.498)\end{array}$ & $\begin{array}{c}0.908^{*} \\
(0.479)\end{array}$ & $\begin{array}{c}0.847^{*} \\
(0.461)\end{array}$ & $\begin{array}{c}0.898^{*} \\
(0.479)\end{array}$ & $\begin{array}{c}0.818^{*} \\
(0.480)\end{array}$ & $\begin{array}{l}1.059 * * \\
(0.487)\end{array}$ & $\begin{array}{l}1.096^{* *} \\
(0.495)\end{array}$ \\
\hline SOE & $\begin{array}{c}-6.902^{* *} \\
(2.662)\end{array}$ & $\begin{array}{l}-4.646^{*} \\
(2.414)\end{array}$ & $\begin{array}{c}-5.253^{* *} \\
(2.321)\end{array}$ & $\begin{array}{c}-5.212^{* *} \\
(2.450)\end{array}$ & $\begin{array}{c}-4.911^{* *} \\
(2.414)\end{array}$ & $\begin{array}{c}-4.871^{* *} \\
(2.425)\end{array}$ & $\begin{array}{c}-6.547^{* * *} \\
(2.504)\end{array}$ \\
\hline RRatio & $\begin{array}{l}0.836^{* *} \\
(0.371)\end{array}$ & & & & & & $\begin{array}{c}0.488 \\
(0.412)\end{array}$ \\
\hline CEO & & $\begin{array}{c}1.888 \\
(1.154)\end{array}$ & & & & & $\begin{array}{c}1.104 \\
(1.141)\end{array}$ \\
\hline RManag & & & $\begin{array}{c}3.921^{* * *} \\
(1.375)\end{array}$ & & & & $\begin{array}{c}2.927^{*} \\
(1.585)\end{array}$ \\
\hline $\mathrm{RR} \& \mathrm{D}$ & & & & $\begin{array}{c}2.370 \\
(1.821)\end{array}$ & & & $\begin{array}{l}-1.161 \\
(2.107)\end{array}$ \\
\hline RSale & & & & & $\begin{array}{c}3.400^{*} \\
(1.793)\end{array}$ & & $\begin{array}{c}2.718 \\
(1.982)\end{array}$ \\
\hline ROther & & & & & & $\begin{array}{c}-28.414 \\
(0.000)\end{array}$ & $\begin{array}{r}-33.319 \\
(0.000)\end{array}$ \\
\hline Constant & $\begin{array}{c}-20.426^{* * *} \\
(4.992)\end{array}$ & $\begin{array}{c}-19.432^{* * *} \\
(4.919)\end{array}$ & $\begin{array}{c}-18.164^{* * *} \\
(4.680)\end{array}$ & $\begin{array}{c}-18.767^{* * *} \\
(4.924)\end{array}$ & $\begin{array}{c}-19.253^{* * *} \\
(4.839)\end{array}$ & $\begin{array}{c}-18.708^{* * *} \\
(4.861)\end{array}$ & $\begin{array}{c}-20.219^{* * *} \\
(4.759)\end{array}$ \\
\hline Sigma & $\begin{array}{c}4.811^{* * *} \\
(0.596)\end{array}$ & $\begin{array}{c}4.875^{* * *} \\
(0.605)\end{array}$ & $\begin{array}{c}4.678^{* * *} \\
(0.579)\end{array}$ & $\begin{array}{c}4.895^{* * *} \\
(0.608)\end{array}$ & $\begin{array}{c}4.849 * * * \\
(0.602)\end{array}$ & $\begin{array}{c}4.883^{* * *} \\
(0.606)\end{array}$ & $\begin{array}{c}4.518^{* * *} \\
(0.557)\end{array}$ \\
\hline Industry effects & Yes & Yes & Yes & Yes & Yes & Yes & Yes \\
\hline Observations & 160 & 160 & 160 & 160 & 160 & 160 & 160 \\
\hline
\end{tabular}

Robust standard errors in parentheses.;

*** $\mathrm{p}<0.01,{ }^{* *} \mathrm{p}<0.05{ }^{*} \mathrm{p}<0.1$.

In general, the coefficients of the control variables are consistent with those obtained by the first stage in Table 3 . Hence, variables such as the age and the size of the firm as well as the education level of employees are not only related to the probability of engaging in OFDI, but also are positively associated with the level of overseas investment. Still, a negative and significant effect is registered for SOEs.

Turning to the variables of interest, also in this case a positive relationship is observed between returnees and levels of OFDI. First, the level of outward FDI is positively correlated with the share of returnees in a firm (Column 1). Along the lines of the discussion in the previous section, we can argue that the presence of returnees provides firms with more confidence about foreign markets, allowing them to increase their financial commitments to OFDI. Secondly, the role of a returnee does matter also to determine the level of investment. Interestingly, however, the results seem to show that it is not the role of CEO returnees, but rather the presence of returnees in the management, which is significantly correlated to the decision to invest larger amounts of capital. This is not entirely surprising, given that it is possible to assume that the CEO is mainly involved in the initial decision about investing or not, as shown in Table 3 . The determination of the amount of capital to commit is mainly a matter for the company's top management. Also, in this case, we find that having returnees 
involved in sales functions has a positive relation with the investment, showing that the returnees' knowledge of foreign market opportunities might reduce the risk associated with larger financial commitments.

\subsection{Returnees and firms' experience}

In the previous sections this study identified some robust relations between a firms' heterogeneous characteristics, the role and functions of returnees and the propensity/intensity of OFDI. Having identified the returnees as the main source of experiential learning, we could expect their role to be especially relevant in latecomer firms with little knowledge of international market, a common feature in emerging markets like China. More specifically, and along the lines of hypothesis 2 and of the literature on latecomer firms (Mathews, 2002; Luo and Tung, 2007), we could claim that firms, pushed by the need to go abroad to secure strategic resources and to access markets, might find in the returnees a channel to offset their ownership and knowledge-related disadvantages. 
Table 5. Tobit estimation results: using OFDI logarithm as dependent variable

\begin{tabular}{|c|c|c|c|c|c|c|}
\hline VARIABLES & $\begin{array}{c}(1) \\
\text { RRatio }\end{array}$ & $\begin{array}{c}2) \\
\text { CEO }\end{array}$ & $\begin{array}{c}\text { (3) } \\
\text { RManag } \\
\end{array}$ & $\begin{array}{c}(4) \\
\text { RR\&D }\end{array}$ & $\begin{array}{c}\text { (5) } \\
\text { RSale }\end{array}$ & $\begin{array}{c}\quad(6) \\
\text { ROther }\end{array}$ \\
\hline Age & $\begin{array}{c}2.925^{*} \\
(1.498)\end{array}$ & $\begin{array}{c}2.837^{*} \\
(1.659)\end{array}$ & $\begin{array}{l}3.457^{* *} \\
(1.528)\end{array}$ & $\begin{array}{l}3.128^{* *} \\
(1.479)\end{array}$ & $\begin{array}{c}2.768^{*} \\
(1.518)\end{array}$ & $\begin{array}{c}2.050 \\
(1.436)\end{array}$ \\
\hline Export & $\begin{array}{l}-0.967 \\
(1.748)\end{array}$ & $\begin{array}{l}-1.095 \\
(1.777)\end{array}$ & $\begin{array}{c}-1.626 \\
(1.708)\end{array}$ & $\begin{array}{c}-0.700 \\
(1.723)\end{array}$ & $\begin{array}{c}-1.372 \\
(1.773)\end{array}$ & $\begin{array}{c}-0.566 \\
(1.736)\end{array}$ \\
\hline Edu & $\begin{array}{c}0.114^{* * *} \\
(0.034)\end{array}$ & $\begin{array}{c}0.111^{* * *} \\
(0.035)\end{array}$ & $\begin{array}{c}0.090^{* * *} \\
(0.033)\end{array}$ & $\begin{array}{c}0.109 * * * \\
(0.034)\end{array}$ & $\begin{array}{c}0.123^{* * *} \\
(0.034)\end{array}$ & $\begin{array}{c}0.123^{* * *} \\
(0.035)\end{array}$ \\
\hline Size & $\begin{array}{l}1.187^{* *} \\
(0.496)\end{array}$ & $\begin{array}{c}0.950^{*} \\
(0.482)\end{array}$ & $\begin{array}{c}0.834^{*} \\
(0.457)\end{array}$ & $\begin{array}{c}0.766 \\
(0.472)\end{array}$ & $\begin{array}{c}0.806^{*} \\
(0.479)\end{array}$ & $\begin{array}{l}1.059 * * \\
(0.487)\end{array}$ \\
\hline SOE & $\begin{array}{c}-6.457^{* *} \\
(2.623)\end{array}$ & $\begin{array}{c}-4.888^{* *} \\
(2.457)\end{array}$ & $\begin{array}{c}-5.209 * * \\
(2.340)\end{array}$ & $\begin{array}{l}-4.651^{*} \\
(2.501)\end{array}$ & $\begin{array}{c}-4.961^{* *} \\
(2.400)\end{array}$ & $\begin{array}{c}-4.871^{* *} \\
(2.425)\end{array}$ \\
\hline RRatio & $\begin{array}{c}2.062^{*} \\
(1.073)\end{array}$ & & & & & \\
\hline RRatio*age & $\begin{array}{l}-0.480 \\
(0.396)\end{array}$ & & & & & \\
\hline RCEO & & $\begin{array}{c}6.292 \\
(7.031)\end{array}$ & & & & \\
\hline RCEO*age & & $\begin{array}{l}-1.685 \\
(2.650)\end{array}$ & & & & \\
\hline RManag & & & $\begin{array}{c}20.777^{* *} \\
(8.222)\end{array}$ & & & \\
\hline RManag*age & & & $\begin{array}{c}-6.289^{* *} \\
(3.000)\end{array}$ & & & \\
\hline $\mathrm{RR} \& \mathrm{D}$ & & & & $\begin{array}{l}29.545^{* *} \\
(12.012)\end{array}$ & & \\
\hline RR\&D*age & & & & $\begin{array}{c}-10.542^{* *} \\
(4.632)\end{array}$ & & \\
\hline RSale & & & & & $\begin{array}{c}10.090 \\
(11.277)\end{array}$ & \\
\hline RSale8age & & & & & $\begin{array}{l}-2.630 \\
(4.377)\end{array}$ & \\
\hline ROther & & & & & & $\begin{array}{r}-28.342 \\
(0.000)\end{array}$ \\
\hline Rother*age & & & & & & $\begin{array}{c}-0.026 \\
(0.000)\end{array}$ \\
\hline Constant & $\begin{array}{c}-21.502^{* * *} \\
(5.121)\end{array}$ & $\begin{array}{c}-20.901^{* * *} \\
(5.513)\end{array}$ & $\begin{array}{c}-21.347^{* * *} \\
(5.069)\end{array}$ & $\begin{array}{c}-19.871^{* * *} \\
(4.912)\end{array}$ & $\begin{array}{c}-20.082^{* * *} \\
(5.069)\end{array}$ & $\begin{array}{c}-18.708^{* * *} \\
(4.861)\end{array}$ \\
\hline Industry effects & Yes & Yes & Yes & Yes & Yes & Yes \\
\hline Sigma & $\begin{array}{c}4.768^{* * *} \\
(0.591)\end{array}$ & $\begin{array}{c}4.864^{* * *} \\
(0.604)\end{array}$ & $\begin{array}{c}4.562^{* * *} \\
(0.563)\end{array}$ & $\begin{array}{c}4.726^{* * *} \\
(0.585)\end{array}$ & $\begin{array}{c}4.838^{* * *} \\
(0.600)\end{array}$ & $\begin{array}{c}4.883^{* * *} \\
(0.606)\end{array}$ \\
\hline Observations & 160 & 160 & 160 & 160 & 160 & 160 \\
\hline
\end{tabular}

Robust standard errors in parentheses,

*** $\mathrm{p}<0.01,{ }^{* *} \mathrm{p}<0.05,{ }^{*} \mathrm{p}<0.1$.

In order to test this hypothesis, we have run our model by interacting the variable representing the experience of firms, i.e. their age, with each of our returnees' indicators. Results, reported in Table 5, show a negative sign of the interaction coefficients, whereas the individual coefficients generally keep their positive (and significant) effect. In line with our theoretical assumptions, this can be explained through a substitution effect between the two variables, which can ultimately be interpreted as the possibility to engage in OFDI for firms with low levels of experience should they have returnees in high value added functions such as management or R\&D. Figure 2 provides a graphic representation that makes the meaning of the interaction coefficient more intuitive. In the graph, the proportional change of OFDI in response to one percentage increase of the age of the firm is set to be dependent on the presence of returnees who sit in the management. The graph clearly shows that the lack of organizational experience 
can be compensated by hiring a manager with overseas experience. While firms without returnees (the dotted line) have larger probabilities (and levels) of overseas investment as they acquire more experience, the opposite is in fact true for firms with returnees in the management (the continuous line). More specifically, the graph shows that this seems the case for newly established firms aged about $4(=\exp (1.38))$ to $10(=\exp (2.38))$ years, which see their probability to go abroad much higher compared to firms from the same age cohort, but without returnees on the board. The crossing point between the two lines suggests that the replacement effect reduces to zero around 27 years, at which the predictive margin of OFDI to Age will be indifferent to the presence of returnees.

Figure 2. Interaction term coefficient (predicted from the specification in column 3 , Table 5)

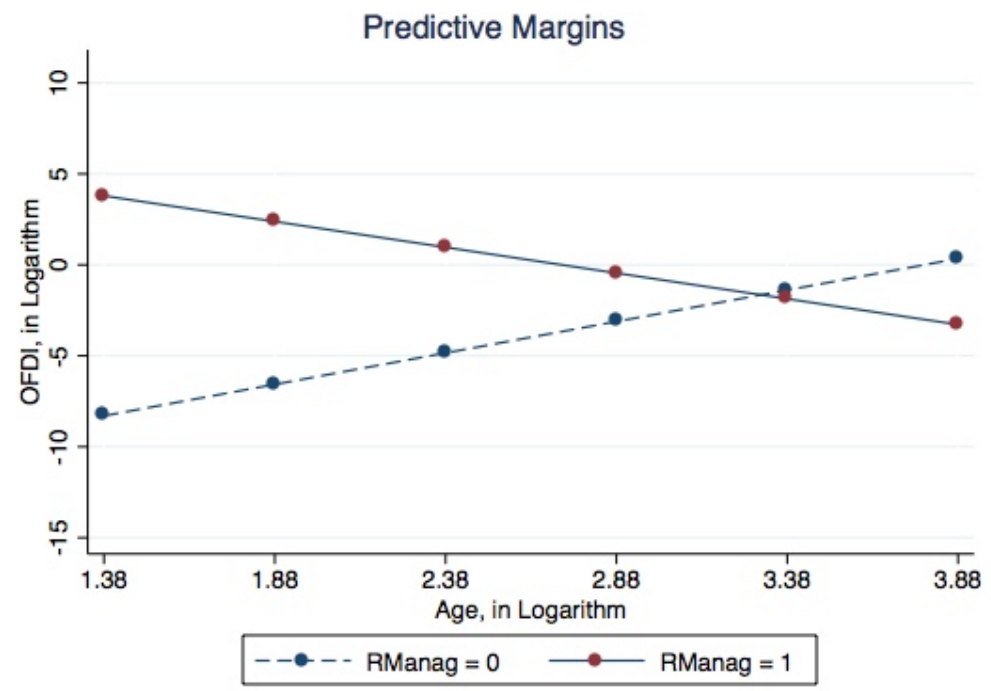

Source: Authors' elaboration on the survey results

This result is consistent with similar findings about Chinese firms by Cui et al. (2013), who interact the variables measuring organizational and managerial international experience (measured as the percentage of managers with foreign experience). They find that the two variables substitute each other, this being due to the urgency of the decisions to invest abroad and to the lack of sufficient resources to build on a more complex decision making process.

There are two potential explanations that can further support this finding. First, returnees, by bringing their own networks, together with knowledge and practices about doing business abroad, can directly offset the lack of knowledge of foreign markets and management capacities of more recently established firms, so far constrained in the successful implementation of the Go Global strategy (Nolan, 2012). Second, returnees in such key functions can indirectly spur internationalization by contributing to increase the overall efficiency of the firms, this generally being a major determinant of investment decision. By bringing in advanced managerial practices and technical knowledge, returnees can contribute to raise more rapidly the productivity and the performance of 
latecomer firms as recently demonstrated by Dai and Liu (2009) or Chen et al. (2015).

\subsection{Robustness check: accounting for the potential endogeneity of Returnees}

The relationship between returnees and outward FDI that we have examined so far can lead to biased results if potential endogeneity is not correctly taken into account. We can think of two main sources of endogeneity in our specific context. Firstly, employees with overseas experience are potential endogenous factors in determining a firm's investment decision and performance due to their strong knowledge-embedded nature. Specifically, the presence of returnees is likely to correlate with firms' productivity level, which is normally an unobserved factor. Unobserved productivity also influences the investment decision-making, being one of the main competitive advantages of firms. Therefore, a potential endogeneity bias may rise due to the omitted productivity in equation (1). Secondly, and even more relevant, the reverse linkage between OFDI and returnees may result in a potential simultaneity bias. With strong ambitions to expand their operations overseas, Chinese multinationals will demand more qualified workers. Returnees who have gained an understanding of both foreign and Chinese business models during their path of internationalization will be especially in demand. From the supply side perspective, returnees are also more willing to work in companies where their skills and ambitions can be duly rewarded. Hence we can expect that the greater the firms' engagement in OFDI, the higher their number of returnees.

In an attempt to remove the bias caused by the potential endogenous nature of returnees, both Probit and Tobit instrumental variable (IV) approaches are used to re-estimate equation (1). Finding a valid instrument that has no partial effect on OFDI while being related, either positively or negatively, to the potentially endogenous explanatory variable, is an extremely challenging task. Also in view of the limitations of the data, in the end we adopt a location dummy as instrument. It equals 1 if a firm is located in Guangzhou and Shenzhen, the two most developed cities in Guangdong province, and zero otherwise. Both cities have been ranked in tier one city group in China, together with Beijing and Shanghai ${ }^{12}$. One of biggest decisions to make when talents consider their return to China is where to settle down. It directly links to another series of substantial concerns such as career platform, quality of life, schools for their children etc. Given the best entrepreneurship environment and supporting resources, tier 1 cities in China attract more returnees than other cities. ${ }^{13}$ Although setting up a firm will normally take into account the location factors at the initial stage, the decision to invest overseas normally comes afterwards and independently of the choice of location, so it can be assumed that location does not have a direct influence on overseas investment.

\footnotetext{
${ }^{12}$ China's first-tier cities usually refer to Beijing, Shanghai, Guangzhou, and Shenzhen which make "The Big 4". Second-tier cities include Tianjin, Chongqing, Chengdu, Wuhan, Xiamen.

${ }^{13}$ As reported by the Ministry of Education (2014) more than half, 56 per cent, of Chinese students are choosing to seek employment opportunities in these tier 1 cities following overseas study in 2013.
} 
Table 6. IV Probit and Tobit estimations

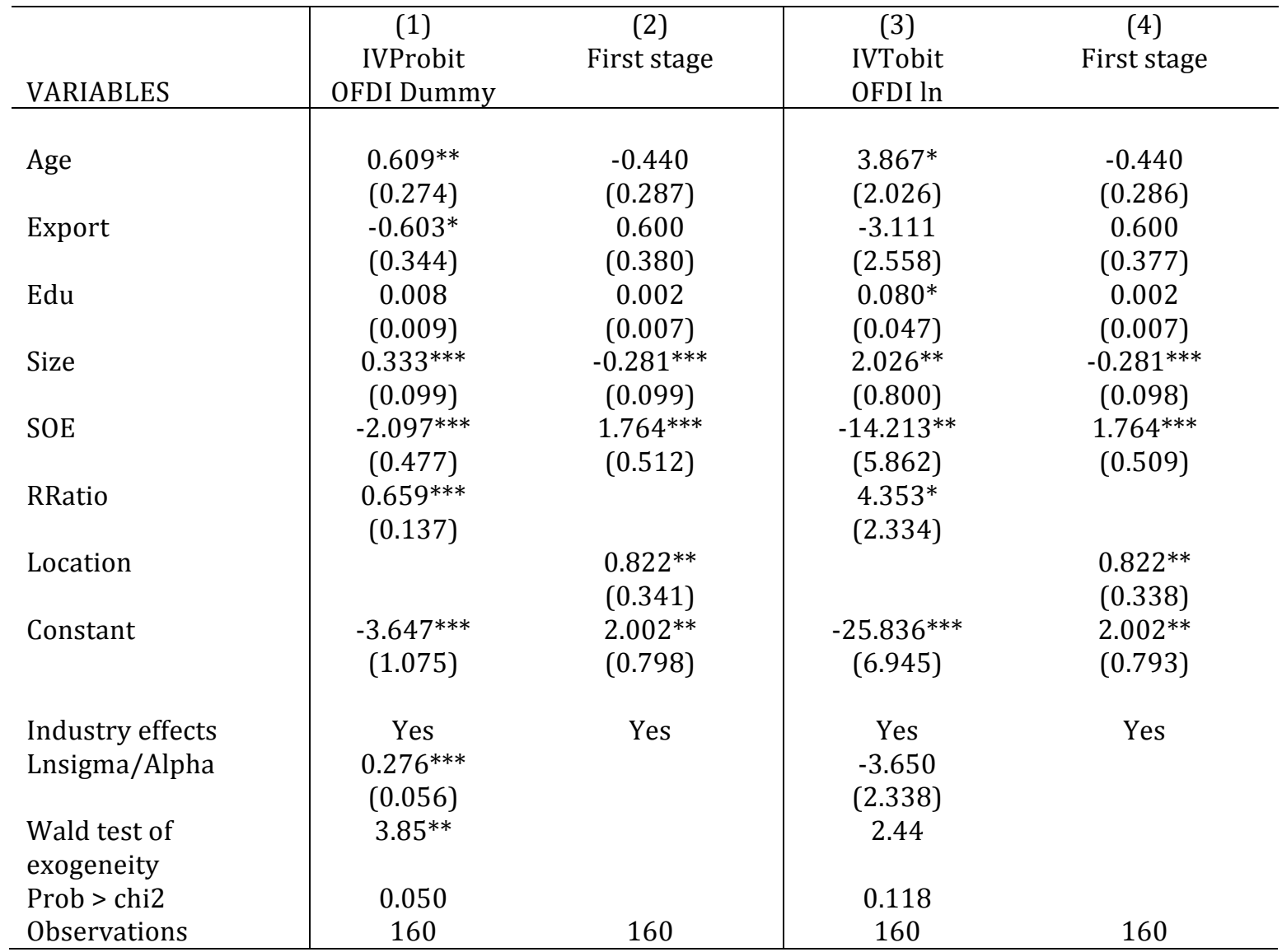

Standard errors in parentheses

${ }^{* * *} \mathrm{p}<0.01,{ }^{* *} \mathrm{p}<0.05{ }^{*} \mathrm{p}<0.1$.

Table 6 displays the estimated coefficients and standard errors (in brackets) of the Probit (Column 1) and the Tobit (Column 2) IV approach. ${ }^{14}$ Columns 2 and 4 present the results of the IV first stage that involves the regression of the main controls and the instrument 'Location' using the potentially endogenous 'Returnees' as dependent variable. First stage results are themselves quite interesting. They show for instance that firms' experience and endowments of human capital are not significantly related to the share of returnees among total employees. They also show that small sized firms and SOEs, for different reasons, are more likely to have a relatively higher number of returnees. Finally, they show that returnees are more likely to settle down in tier 1 cities (Guangzhou and Shenzhen), where they can find better career opportunities and living facilities, confirming that the selected instrument has a direct relation with the potentially endogenous variable.

Moving to the main results, in both cases they show that the coefficient of returnees keeps its positive and significant influence on both the propensity and the intensity of OFDI, leaving us quite confident about the results reported in Tables 3 and 4 and discussed in the previous sections.

14 The primary objective here is to check if 'returnees' is an endogenous variable in affecting OFDI intensity and so if such potential endogeneity would affect our main results. With regard to other specifications such as the models $2-6$ in tables 2 and 3, Probit and Tobit IV are not feasible since these approaches require the endogenous explanatory variables to be continuous in values. 
Still, however, when we look at the results of the Wald test at the bottom of the table, the endogenous property of RRatio is statistically confirmed only for the Probit model. This is not surprising, considering that the risk of an endogenous relation between returnees and OFDI is more likely to be determined by the effective engagement of firms overseas rather than on the size of their financial commitments.

\section{Conclusions}

Recent years have witnessed an increased interest in the study of the pattern of Chinese OFDI and of the internationalization process of domestic firms. Still, while some of the existing literature has identified the lack of experience and management capacities in Chinese firms to be a potential bottleneck to successful internationalization (Fu et al., 2013), little has been said on the way knowledge and experience of foreign markets and international operations is actually acquired.

Within such context, this work has analyzed the role of returnees as a source of knowledge spillovers and as a potential driver of internationalization for domestic firms. The contribution of the empirical results, based on an original survey focusing on the "Going Global" strategies of firms in the province of Guangdong, to the existing literature is threefold. First, our work confirms that there is a strong and positive relation between firms' choice of hiring returnees and their propensity to embark in active internationalization through FDI. Second, going a bit deeper into the previous finding, we show that not all the returnees contribute to a firms' internationalization in a similar way. It is mainly those individuals sitting in the most strategic positions, such as management and sales departments, who determine both the propensity and the intensity of FDI. Third, the presence of returnees is particularly effective for less experienced firms since it can help reduce the time taken to acquire resources and provide direct access to the knowledge necessary to invest abroad.

This study contributes to the literature not only by providing rare firm level evidence from China confirming the role of returnees in the internationalization process in the emerging markets companies, but also revealing that the impact of the returnees will be different depending on their specific roles in the companies and their companies experience in international operation. This is an important distinction, which helps to better identify the contribution of returnees, and improve on the existing evidence, most of which has focused so far on general questions such as whether a firm has employed returnee staff or how many there are. Our results hence add to the literature that argues that the extent to which returnees can affect internationalization is moderated by the effective role they play (Cui et al., 2014), and their capacity to affect a company's corporate governance (Lee and Roberts, 2015; Giannetti et al., 2015).

Findings from the research have important policy and practical implications. First, this study suggests that, by hiring returnees, firms can reduce the timing to access knowledge about foreign markets. Importantly, we are able to add that 
the contribution of returnees as sources of experiential knowledge on foreign markets is dependent on their specific role within the firm. Returnees in the management, but not necessarily the CEOs, and sales functions are more likely to contribute directly to internationalization compared to other functions, such as finance and human resources management, whose role is more complementary to build in-house capabilities and enhance the overall performance.

This latter evidence reflects important changes in corporate governance practices in emerging economies (Filatotchev et al. 2007), including in the context of Chinese firms (Shapiro et al., 2015). Increased complexity related with internationalization raises the demand of managerial capacities to adapt to changing environments (Lien et al., 2005). Returnees sit in strategic positions allow firms from emerging economies to conform to existing corporate governance models with new institutional norms and global practices (Lee and Roberts, 2015). Not only their contribution is important in firms with weak corporate governance or with agency problems, such as State controlled ones (Ramasamy et al., 2012). By diversifying the ownership structure of the firm, returnees can also support more risky strategies, including FDI, by balancing decision making power of more conservative CEOs, this being especially true in private firms controlled by the founder or family-owned ones (Hu and Cui, 2014; Giannetti et al., 2015).

Secondly, less experienced firms from emerging markets can obtain knowledge and capabilities in international operation quickly by attracting diaspora talents trained abroad. Therefore, for young firms that targeted an international market or need to source important natural or strategic assets through overseas direct investment, employing suitable returnees to relevant strategic positions and hence tapping in the international knowledge and experiences that these returnees enjoy can serve as a 'short-cut' to enable these firms to quickly acquire necessary capabilities for internationalization.

Thirdly, our research seems to confirm the benefits of the policies that aim to attract highly skilled talents. In addition to their positive contribution to the "Going Out" policy of China, considering that the lack of managerial capacities has been often listed among the main causes of lower productivity of Chinese firms, the injection of qualified human capital from returnees is certainly accelerating the upgrading process of the domestic industry.

Still, this work has some limitations that need to be addressed in further research in order to achieve a better understanding of the role of returnees in the globalization of Chinese firms. The lack of a panel dimension in the data is a major limitation, since it does not allow more precise definition of the direction of causality among the variables, nor more precise investigation of the dynamics of such relations. Also the lack of information on the characteristics of returnees does not allow testing of some more detailed hypotheses, putting in relation, for instance, the geographic boundaries of their transnational network with the final destination of OFDI or to differentiate, as for instance Cui et al. (2013) did, between those with working and those with educational experience gained abroad. Finally, the lack of information on the composition of company boards, 
including on the decision-making process and the different role of power-holding agents, do not allow investigation of how the presence of returnees at different levels of management shapes strategic choice mechanisms. This issue is of great interest to improving our knowledge on Chinese MNEs, especially if combined with a corporate governance perspective, crucial to understanding the different types of organizational structure that actually coexist in the country. 


\section{References}

Agrawal, A., D. Kapur, J. McHale, and A. Oettl (2011) Brain drain or brain bank? The impact of skilled emigration on poor-country innovation, Journal of Urban Economics, 69: 43-55.

Bail, H.L. and W. Shen (2008) The return of the "brains" to China: What are the social, economic and political impacts? IFRI Working Paper, November 2008.

Buckley, P. (2009). The impact of the global factory on economic development. Journal of World Business, 44: 131-143.

Buckley, P.J., L.J. Clegg, A.R. Cross, X. Liu, H. Voss, and P. Zheng (2007) The determinants of Chinese outward foreign direct investment, Journal of International Business Studies, 38 (4): 499-518.

Buckley, P.J., A.R. Cross, H. Tan, L Xin,. and H. Voss (2008) Historic and Emergent Trends in Chinese Outward Direct Investment, Management International Review, 48(6): 715-748.

Chen, P.L., D. Tan, and R.J. Jean, (2015) Foreign knowledge acquisition through inter-firm collaboration and recruitment: Implications for domestic growth of emerging market firms, International Business Review, http://dx.doi.org/10.1016/j.ibusrev.2015.01.009.

Chen, Z. and T. Fang, (2016) Chinese Returnees and High-tech Sector Outward FDI: The Case of Changzhou, IZA Discussion Paper No. 10045.

Child, J. (1972) Organizational Structure, Environment and Performance: The Role of Strategic Choice, Sociology, 6: 1-22.

Child, J. (1997) Strategic Choice in the Analysis of Action, Structure, Organizations and Environment: Retrospect and Prospect, Organization Studies, 18(1): 43-76.

Child, J. and S.B. Rodrigues (2005) The Internationalization of Chinese Firms: A Case for Theoretical Extension? Management and Organizational Review, 1(3): 381-410.

China Statistic Year Book $(2007,2015)$ National Bureau of Statistics of the People's Republic of China. www.stats.gov.cn..

Cohen, W.M. and D.A. Levinthal. (1990). Absorptive Capacity: A New Perspective on Learning and Innovation. Administrative Science Quarterly, 35:128-152.

Cui, L., Y. Li, and Z. Li (2013) Experiential drivers of foreign direct investment by late-comer Asian firms: The Chinese evidence, Journal of Business Research, http://dx.doi.org/10.1016/j.jbusres.2013.05.034.

Cui, L., Y. Li, K.E. Meyer, and Z. Li (2014) Leadership Experience Meets Ownership Structure: Returnee Managers and Internationalization of Emerging Economy Firms, Management International Review, 55: 355-387.

Dai, O. and X. Liu (2009) Returnee entrepreneurs and firm performance in Chinese high-technology industries, International Business Review, 18: 373-386.

Deng, P. (2012). The Internationalization of Chinese Firms: A Critical Review and Future Research, International Journal of Management Reviews, 14: 408-427.

Docquer, F. and H. Rapoport (2012) Globalization, Brain Drain, and Development, Journal of Economic Literature, 50(3): 681-730.

Economist Intelligence Unit (EIU) (2010) A brave new world - The climate for Chinese $M \& A$ abroad, Economist Intelligence Unit. 
Farole, T. and D. Winkler (2012) Foreign Firm Characteristics, Absorptive Capacity and the Institutional Framework. Policy Research Working Paper, WPS6265. The World Bank.

Filatotchev, I., Strange, R. Piesse, J. and Y.C. Lien (2007) FDI by firms from newly industrialised economies in emerging markets: corporate governance, entry mode and location, Journal of International Business Studies, 38: 556-572.

Filatotchev, I., X. Liu, T. Buck and M. Wright (2009). The export orientation and export performance of high-technology SMEs in emerging markets: The effects of knowledge transfer by returnee entrepreneurs. Journal of International Business Studies, 40: 1005-1021.

$\mathrm{Fu}, \mathrm{X}$. (2012) 'FDI and managerial knowledge spillovers through the diffusion of management practices', Journal of Management Studies, 2012, 49(5), 970-999.

Fu, X., S. Liu and T. Li, (2013) The determinants and impact of outward direct investment from China: evidence from Guangdong Survey, University of Oxford, TMCD Centre Working Paper no. 051.

Gao, L., X. Liu and H. Zou (2013) The role of human mobility in promoting Chinese outward FDI: A neglected factor? International Business Review, 22(2): 437449.

Gereffi, G. 1999. International trade and industrial upgrading in the apparel commodity chain. Journal of International Economics, 48(1): 37-70.

Giannetti, M., G. Liao, and X. Yu (2015) The brain gain of corporate boards: evidence from China, the Journal of Finance, DOI: 10.1111/jofi.12198.

Guangdong Provincial Party Committee (2015) Guangdong Youth Entrepreneurship and Employment Blue Book 2015. Guangdong.

Guangdong Human Resource and Social Security Bureau. http://www.gdhrss.gov.cn/.

Hu, H.W. and L. Cui (2014) Outward foreign direct investment of publicly listed firms from China: A corporate governance perspective, International Business Review, 23(4): 750-760.

Johanson, J. and J. Vahlne (1977) The Internationalization Process of the Firm-A Model of Knowledge Development and Increasing Foreign Market Commitments, Journal of International Business Studies, 8 (1): 23-32.

Kenney, M., Breznitz, D. and M. Murphree (2013) Coming back home after the sun rises: Returnee entrepreneurs and growth of high tech industries, Research Policy, 42: 391-407.

Lee, J.H. and Roberts, M.J.D. (2015) International returnees as outside directors: A catalyst for strategic adaptation under institutional pressure, International Business Review, 24: 594-604.

Li, P. P. (2007) Toward an Integrated Theory of Multinational Evolution: The Evidence of Chinese Multinational Enterprises as Latecomers, Journal of International Management, 13: 296- 318.

Lien, Y.C., Piesse, J., Strange, R. and I. Filatotchev (2005) The role of corporate governance in FDI decisions: Evidence from Taiwan, International Business Review, 14: 739-763.

Liu, X., Lu, J., Filatotchev, I., Buck, T. and M. Wright (2010) Returnee entrepreneurs, knowledge spillovers and innovation in high-tech firms in emerging economies, Journal of International Business Studies, 41: 183-197. 
Lu, J., Liu, X. and Wang, H. (2011) Motives for outward FDI of Chinese private firms: Firm resources, industry dynamics, and government policies. Management and Organizational Review, 7 (2): 223-248.

Luo, S., Lovely, M. and D. Popp (2013) Intellectual Returnees as Drivers of Indigenous Innovation: Evidence from the Chinese Photovoltaic Industry, presented at 35th DRUID Celebration Conference, Barcelona.

Luo, Y. and L.R. Tung (2007) International expansion of emerging market enterprises: A springboard perspective, Journal of International Business Studies, 38: 481-498.

Mathews, J. A. (2002) Dragon Multinationals- A new model for global growth. Oxford: Oxford University Press.

Nelson, R. and Phelps, E. S. (1966) Investment in Humans, Technological Diffusion and Economic Growth, American Economic Review, vol.56 (2).

Nolan, P. (2012) Is China Buying the World? Cambridge (UK): Polity Press.

Rabbiosi, L. and T. Stucchi (2012) The Magic of Diasporas: The Role of Overseas National Ownership in Outward FDI of Emerging Market Firms, presented at third Emerging Multinationals Conference, Copenhagen Business School.

Ramasamy, B., Yeung, M. and S. Laforet (2012) China's outward foreign direct investment: Location choice and firm ownership, Journal of World Business, 47(1): 17-25.

Rugman, A. and J. Li (2007) Will China's Multinationals Succeed Globally or Regionally? European Management Journal, 25(5): 333-343.

Saxenian, A. (2006) The New Argonauts: Regional Advantage in a Global Economy, California: Thousand Oaks.

Sinani, E., and K. Meyer (2004) Spillovers of technology transfer from FDI: the case of Estonia, Journal of Comparative Economics, Vol. 32, Issue 3, 445-66.

Shapiro, D., Tang, Y., Wang, M. and Zhang, W. (2015) The effects of corporate governance and ownership on the innovation performance of Chinese SMEs, Journal of Chinese Economic and Business Studies, 14(4): 311-335.

Spigarelli, F., I. Alon, and A. Mucelli (2013) Chinese overseas M\&A: overcoming cultural and organisational divides, Int. J. Technological Learning, Innovation and Development, 6(1/2): 190-208.

The Ministry of Education (2014) Chinese Blue Book on the Employment of Overseas Returnees. The Ministry of Education, Beijing.

Wadhwa, V., J. Sonali, A. Saxenian, G. Gereffi, and H. Wang, (2011) The Grass is Indeed Greener in India and China for Returnee Entrepreneurs - America's New Immigrant Entrepreneurs, Part VI, Kauffman Foundation for Entrepreneurship, April 2011. http://www.kauffman.org/uploadedfiles/grass-is-greener-forreturnee-entrepreneurs.pdf.

Wang, H., D. Zweig, and X. Lin (2011) Returnee Entrepreneurs: impact on China's globalization process, Journal of Contemporary China, 20(70): 413-431.

Wang, H. (2012) Globalizing China - the influence, strategies and successes of Chinese Returnee Entrepreneurs, Bingley (UK): Emerald.

Welch, A. and Z. Zhang, (2007). The rise of the Chinese knowledge diaspora: Possibilities, problems and prospects for South and North. Paper presented at the World University Network Forum Realising the Global University, London. 